\title{
What Do the Democrats Need to be Relevant?
}

\author{
Devin T. Rafferty ${ }^{1}$
}

This paper examines the federal and state-level outcomes of the 2016 election cycle to argue that the Democratic Party is increasingly becoming irrelevant. As a result, the question is posed 'What do the Democrats need to do to be relevant?' To answer it, county-level data from the most politically strategic important areas of the country are analyzed. What the data shows is that the dominant issue of the past election, at least implicitly, was economic inequality. Hence, to solve this widespread issue, a Green New Deal platform is put forward that will solve virtually all of the economic crises facing the lower and middle classes, while additionally mitigating manmade climate change. However, doing so will face opposition from entrenched interests. To compensate, a political strategy is put forth that will enable progressive interests to ensure an ability to adequately implement a Green New Deal, tackle economic inequality, and make traditionally Democratic ideals relevant once again. [Article copies available for a fee from The Transformative Studies Institute. E-mail address:journal@transformativestudies.org Website:

http://www.transformativestudies.org (C2018 by The Transformative Studies Institute. All rights reserved.]

KEYWORDS: 2016 U.S. Election, Economic Inequality, Neoliberalism, Class Conflict, Green New Deal, Democratic Party.

\section{INTRODUCTION}

When the dust cleared from the 2016 U.S. Presidential election, a singular theme stretched across the Presidential, Congressional, and Gubernatorial elections: the Democrats had essentially become irrelevant. Indeed, outside of the traditional Democratic strongholds of the Northeast and West, the final results were not pretty. In the House of

\footnotetext{
${ }^{1}$ Devin T. Rafferty, Ph.D., is an Assistant Professor in the Department of Economics and Finance at Saint Peter's University in Jersey City, New Jersey. Assistant Professor of Economics and Finance, Saint Peter's University, Jersey City, NJ 07306. Address correspondence to: Dr. Devin T. Rafferty, e-mail: Devin.T.Rafferty@gmail.com.
} 